\title{
Cohaesibacter gelatinilyticus gen. nov., sp. nov., a marine bacterium that forms a distinct branch in the order Rhizobiales, and proposal of Cohaesibacteraceae fam. nov.
}

\author{
Chung Yeon Hwang and Byung Cheol Cho
}

Correspondence

Byung Cheol Cho

bccho@snu.ac.kr
School of Earth and Environmental Sciences and Research Institute of Oceanography, Seoul National University, Shillim-dong, Kwanak-gu, Seoul 151-742, Republic of Korea
The class Alphaproteobacteria comprises the seven orders Caulobacterales, 'Parvularculales', Rhizobiales, Rhodobacterales, Rhodospirillales, Rickettsiales and Sphingomonadales (Garrity et al., 2005). The order Rhizobiales is a phenotypically heterogeneous assemblage within the $\alpha-2$ subgroup of the Proteobacteria (Woese et al., 1984), and is divided into 10 families on the basis of 16S rRNA gene sequence analyses (Kuykendall, 2005a): Rhizobiaceae, Bartonellaceae, Brucellaceae, Phyllobacteriaceae, Methylocystaceae, Beijerinckiaceae, Bradyrhizobiaceae, Hyphomicrobiaceae, Methylobacteriaceae and Rhodobiaceae. In addition to these families, a new family was described as 'Aurantimonadaceae' and contains the genera Aurantimonas and Fulvimarina within the order Rhizobiales

The GenBank/EMBL/DDBJ accession number for the 16S rRNA gene sequence of strain CL-GR15 ${ }^{\top}\left(=\mathrm{KCCM} 42319^{\top}=\mathrm{DSM} 18289^{\top}\right)$ is D0386307.

Supplementary figures are available with the online version of this paper.
(Garrity et al., 2004). Recently, phylogenetic analysis of $16 \mathrm{~S}$ rRNA gene sequences excluding six variable regions for 261 species in the class Alphaproteobacteria revealed another family, 'Xanthobacteraceae', within the order Rhizobiales (Lee et al., 2005). In this paper, two strains representing a novel family-level lineage within the order Rhizobiales were isolated and characterized by polyphasic approaches (Vandamme et al., 1996).

A coastal water sample was incubated with sand sediment in a $150 \mathrm{~mm}$ diameter glass Petri dish at room temperature for about 5 months. Without disturbing the sediment, $100 \mu \mathrm{l}$ superficial seawater was taken and spread on a plate containing R2A agar (Difco) supplemented with 3\% (w/v) $\mathrm{NaCl}$, and the plate was incubated at $25{ }^{\circ} \mathrm{C}$ for 5 days. Strains CL-GR $15^{\mathrm{T}}$ and CL-GR35 were isolated from the same plate and subsequently purified on R2A agar supplemented with $3 \%(\mathrm{w} / \mathrm{v}) \mathrm{NaCl}$ at $25{ }^{\circ} \mathrm{C}$ four times. The strains were able to grow well on marine agar 2216 (MA; Difco) as well as R2A agar supplemented with $3 \%$ 


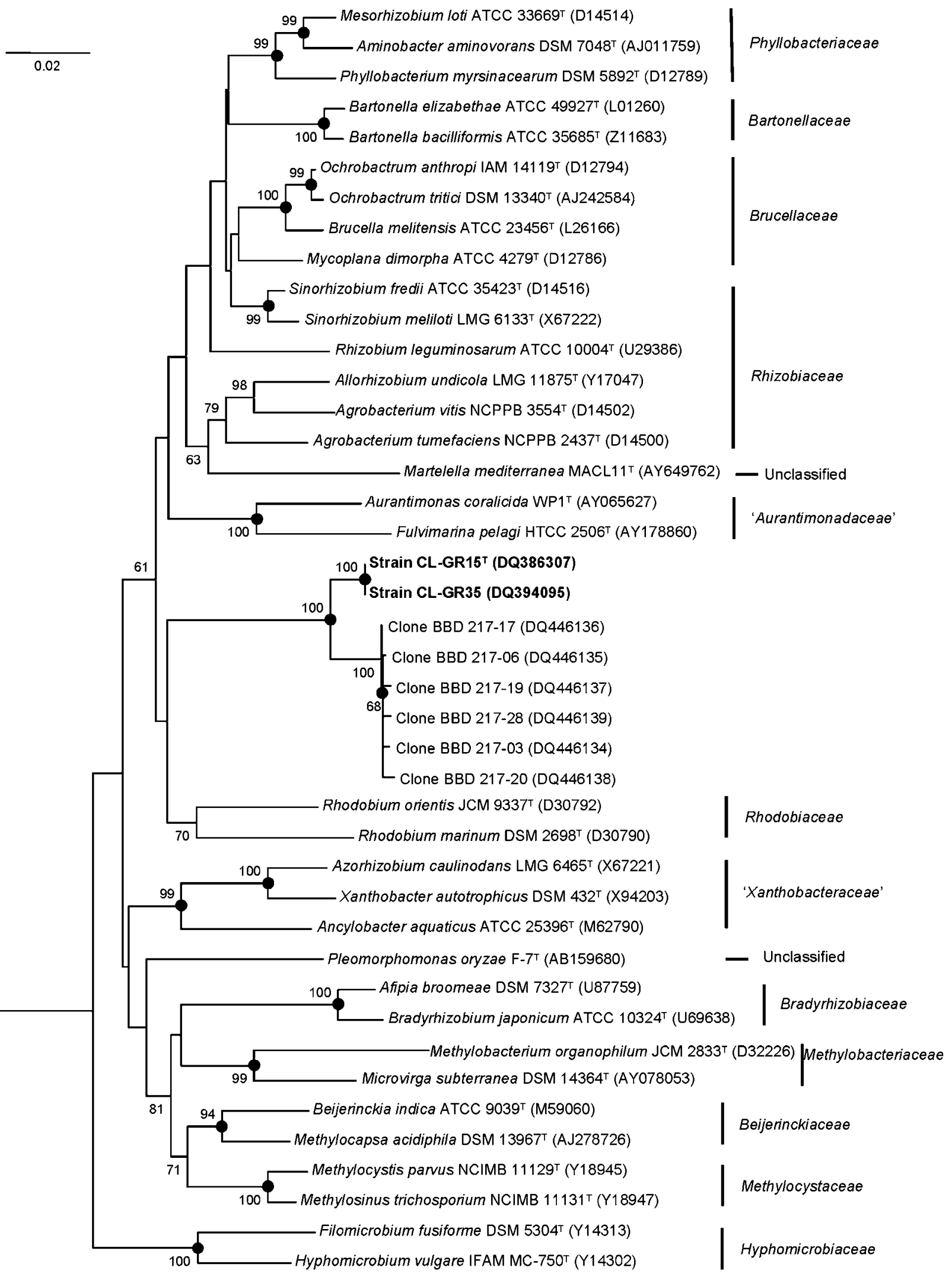

Escherichia coli K-12 (U00096) 
$(\mathrm{w} / \mathrm{v}) \mathrm{NaCl}$. The strains were maintained on $\mathrm{MA}$ at 25 $30{ }^{\circ} \mathrm{C}$ and stored frozen at $-80{ }^{\circ} \mathrm{C}$ as described by Choi et al. (2006).

The $16 \mathrm{~S}$ rRNA gene was amplified from a single colony by using Taq DNA polymerase (Bioneer) and primers $27 \mathrm{~F}$ and 1492R (Lane, 1991). The PCR product was purified by using the AccuPrep PCR Purification kit (Bioneer), and direct sequence determination of the purified 16S rRNA gene was performed with an Applied Biosystems automated sequencer (ABI3730XL) at Macrogen (Seoul, Korea). The almost-complete $16 \mathrm{~S}$ rRNA gene sequences of strains CL-GR15 ${ }^{\mathrm{T}}$ (1374 bp) and CL-GR35 (1344 bp) were obtained and compared with those available in GenBank using BLASTN searches (Altschul et al., 1990). The sequences of strains CL-GR $15^{\mathrm{T}}$ and CL-GR35 were manually aligned with those of 189 species with validly published names belonging to related families in the order Rhizobiales, obtained from GenBank and the Ribosomal Database Project (Cole et al., 2003) databases, using known $16 \mathrm{~S}$ rRNA secondary structure information. Phylogenetic trees were obtained by neighbour-joining (Saitou \& Nei, 1987) and maximum-parsimony (Fitch, 1971) methods. An evolutionary distance matrix for the neighbour-joining method was generated according to the model of Jukes \& Cantor (1969). The robustness of tree topologies was assessed by bootstrap analyses based on 1000 replications for neighbour-joining and maximum-parsimony methods. Alignment analysis was carried out using the jPHYDIT program (Jeon et al., 2005), and phylogenetic analyses were carried out using MEGA3 (Kumar et al., 2004).

Signature nucleotides present within 16S rRNA genes were searched for using the sequences aligned for the phylogenetic analysis. Only those positions were selected for signatures for which the majority of families each exhibited a single nucleotide. Every signature nucleotide found was then positioned on the secondary structure of the $16 \mathrm{~S}$ rRNA molecule of Escherichia coli (Ivanova et al., 2004).

Morphological and physiological tests were performed as follows. Gram-staining was performed as described by Smibert \& Krieg (1994). Cellular morphology and the presence of flagellum were observed using transmission electron microscopy (EX2; JEOL). Motility was determined by the hanging drop method (Smibert \& Krieg, 1994). Anaerobic growth was checked on MA using the GasPak anaerobic system (BBL). Bacteriochlorophyll $a$ production was determined in acetone extracts from cells cultured in the light and the dark, and examined with an Ultraspec 2000 spectrophotometer (Pharmacia Biotech). Poly- $\beta$ hydroxybutyrate granules were observed by epifluorescence microscopy (BX60; Olympus) after Nile blue A staining
(Ostle \& Holt, 1982). Growth was tested on trypticase soy agar (TSA; BBL), fivefold-diluted TSA, Czapek-Dox agar (Weyland, 1969), MacConkey agar (Difco) and blood agar (Difco) or the above media supplemented with either 3\% (w/v) $\mathrm{NaCl}$ or $3 \%(\mathrm{w} / \mathrm{v})$ sea salts (Sigma). The temperature range for growth was tested on the basis of colony formation on MA plates incubated at 5, 10, 15, 20, 25, $30,31,33,35$ and $40{ }^{\circ} \mathrm{C}$. The $\mathrm{pH}$ range $(\mathrm{pH} 4-10$ at intervals of $1 \mathrm{pH}$ unit) for growth was determined both on the basis of colony formation on MA plates and assessing changes in $\mathrm{OD}_{600}$ in $\mathrm{pH}$-buffered marine broth medium (Difco) (Manaia et al., 2003). To test salt tolerance, R2A agar (Difco) containing various concentrations of $\mathrm{NaCl}[0$, $0.5,1,2,3,5,7,10,15,20,25$ and $30 \%(\mathrm{w} / \mathrm{v})]$ were used. Catalase and oxidase activities and degradation of casein, cellulose, xanthine and hypoxanthine were determined according to the protocols described by Smibert \& Krieg (1994). In addition, nitrate reduction, the production of indole, arginine dihydrolase, urease, gelatinase and the hydrolysis of aesculin were tested using the API 20NE kit (bioMérieux) according to the manufacturer's instructions, except that the cell suspension was supplemented with $\mathrm{NaCl}(3 \%$, w/v). Other enzyme activities and acid productions were assayed using the API ZYM and the API $50 \mathrm{CH}$ kits (bioMérieux), respectively, with $3 \% \mathrm{NaCl}$ solution as the suspension medium. Carbon utilization was tested using basal medium supplemented with $0.01 \%$ $(\mathrm{w} / \mathrm{v})$ yeast extract (Tris/ $\mathrm{HCl}, 50 \mathrm{mM}, \mathrm{pH} 7.5 ; \mathrm{NH}_{4} \mathrm{Cl}$, $19 \mathrm{mM} ; \quad \mathrm{K}_{2} \mathrm{HPO}_{4} .3 \mathrm{H}_{2} \mathrm{O}, 0.33 \mathrm{mM}$ and $\mathrm{FeSO}_{4} .7 \mathrm{H}_{2} \mathrm{O}$, $0.1 \mathrm{mM}$ in artificial seawater; Baumann \& Baumann, 1981) containing $0.1 \%$ carbon source based on changes in $\mathrm{OD}_{600}$ over 4 weeks. Sensitivities to antibiotics were carried out using disc-diffusion methodology (Bauer et al., 1966). All phenotypic assays (except analysis of the temperature range) were carried out at $25-30{ }^{\circ} \mathrm{C}$, which was the range of optimal growth temperature for strains CL-GR $15^{\mathrm{T}}$ and CL-GR35.

Polar lipids were extracted using the procedures described by Minnikin et al. (1984) and identified by twodimensional TLC followed by spraying with appropriate detection reagents (Komagata \& Suzuki, 1987). The fatty acid methyl esters in whole cells, which were grown on MA at $30{ }^{\circ} \mathrm{C}$ for 4 days, were analysed by gas chromatography according to the instruction of the Microbial Identification System (MIDI) at the Korean Culture Center of Microorganisms (KCCM) in Seoul, Korea. The quinone system was determined according to Minnikin et al. (1984) and analysed by HPLC as described by Collins (1985). The DNA G + C content was analysed by HPLC (HP 100; Hewlett Packard) analysis of deoxyribonucleosides as described by Mesbah et al. (1989), after DNA extraction

Fig. 1. Neighbour-joining tree showing relationships between the strains studied and representatives of related families in the order Rhizobiales. Only bootstrap values (expressed as percentage of 1000 replications) greater than $60 \%$ are shown at nodes. Solid circles indicate that the corresponding nodes are also recovered in maximum-parsimony trees. Bar, 0.02 nucleotide substitutions per site. 
Table 1. Selected 16S rRNA gene signature nucleotides for the families of the order Rhizobiales

Lower-case letters indicate bases found in less than $50 \%$ of assayable cases. Positions follow E. coli numbering.

\begin{tabular}{|c|c|c|c|c|c|c|}
\hline Position & $129-232$ & 194 & 297 & $600-638$ & $678-712$ & $1244-1293$ \\
\hline Cohaesibacteraceae fam. nov. & $A-G$ & $\mathrm{~T}$ & G & $\mathrm{A}-\mathrm{T}$ & $\mathrm{A}-\mathrm{T}$ & $\mathrm{A}-\mathrm{T}$ \\
\hline Brucellaceae & $A-G$ & G & G & $\mathrm{A}-\mathrm{T}$ & $\mathrm{T}-\mathrm{A}$ & $\mathrm{G}-\mathrm{C}$ \\
\hline Bartonellaceae & $A-G$ & G & G & $\mathrm{A}-\mathrm{T}$ & $\mathrm{T}-\mathrm{A}$ & $\mathrm{G}-\mathrm{C}$ \\
\hline 'Aurantimonadaceae' & $A-G$ & G & A & $\mathrm{A}-\mathrm{T}$ & $\mathrm{T}-\mathrm{A}$ & $\mathrm{G}-\mathrm{C}$ \\
\hline Rhodobiaceae & $A-G$ & G & G & $\mathrm{A}-\mathrm{T}$ & $\mathrm{T}-\mathrm{A}$ & $\mathrm{G}-\mathrm{C}$ \\
\hline Phyllobacteriaceae & $A-G$ & G & G & $\mathrm{A}-\mathrm{T}$ & $\mathrm{T}-\mathrm{A}$ & $\mathrm{G}-\mathrm{C}$ \\
\hline Rhizobiaceae & $A-G$ & G & G & $\mathrm{A}-\mathrm{T}$ & $\mathrm{T}-\mathrm{A}$ & $\mathrm{G}-\mathrm{C}$ \\
\hline 'Xanthobacteraceae' & $\mathrm{G}-\mathrm{A}$ & G & G & $\mathrm{A}-\mathrm{T}$ & $\mathrm{T}-\mathrm{A}$ & $\mathrm{G}-\mathrm{C}$ \\
\hline Bradyrhizobiaceae & $A-G$ & G & G & $\mathrm{A}(\mathrm{g})-\mathrm{T}(\mathrm{c})$ & $\mathrm{T}-\mathrm{A}$ & $\mathrm{G}-\mathrm{C}$ \\
\hline Methylobacteriaceae & $A-G$ & G & G & $\mathrm{G}-\mathrm{C}$ & $\mathrm{T}-\mathrm{A}$ & $\mathrm{G}-\mathrm{C}$ \\
\hline Beijerinckiaceae & $A-G$ & G & G & $\mathrm{A}-\mathrm{T}$ & $\mathrm{T}-\mathrm{A}$ & $\mathrm{G}-\mathrm{C}$ \\
\hline Methylocystaceae & $\mathrm{A}(\mathrm{g})-\mathrm{G}(\mathrm{a})$ & G & G & $\mathrm{A}-\mathrm{T}$ & $\mathrm{T}-\mathrm{A}$ & $\mathrm{G}-\mathrm{C}$ \\
\hline Hyphomicrobiaceae & $A(g)-G(a)$ & G & G & $\mathrm{A}(\mathrm{g})-\mathrm{T}(\mathrm{c})$ & $\mathrm{T}-\mathrm{A}$ & $\mathrm{G}(\mathrm{a})-\mathrm{C}(\mathrm{t})$ \\
\hline
\end{tabular}

by the method of Marmur (1961). Lambda DNA was used as a standard. The relatedness of genomic DNA between strains CL-GR $15^{\mathrm{T}}$ and CL-GR35 was determined by dotblot hybridization as described by Choi et al. (2006).

Direct sequencing of the 16S rRNA gene revealed that sequences of strains CL-GR $15^{\mathrm{T}}$ and CL-GR35 were identical, and showed $96.2-96.4 \%$ sequence similarity to clones obtained from black band-diseased corals located at water depths of 24 and $27 \mathrm{~m}$ (Sekar et al., 2006; Fig. 1). Sequence comparisons to representative bacteria with validly published names indicated that strains CL-GR $15^{\mathrm{T}}$ and CL-GR35 belonged to the order Rhizobiales in the Alphaproteobacteria (Fig. 1; see a global tree available as Supplementary Fig. S1 in IJSEM Online). The strains were most closely related to the genera Ochrobactrum and Brucella in the family Brucellaceae (90.9-92.5\% similarity), the genus Sinorhizobium in the family Rhizobiaceae (90.9$91.5 \%)$, the genus Bartonella in the family Bartonellaceae (90.6-91.9\%), the genus Rhodobium in the family Rhodobiaceae (89.3-91.2\%) and the genus Phyllobacterium in the family Phyllobacteriaceae (89.3-91.2\%). In all phylogenetic trees, strains CL-GR $15^{\mathrm{T}}$ and CL-GR35, together with the recently observed clone sequences from black band-diseased corals (Sekar et al., 2006), form a distinct monophyletic clade with $100 \%$ bootstrap within the order Rhizobiales (Fig. 1, Supplementary Fig. S1). Further, this lineage could not be associated with any of the 12 known families and two unclassified genera in the order Rhizobiales. In addition, ten $16 \mathrm{~S}$ rRNA gene signature nucleotides for the families of the order Rhizobiales were detected (Table 1). Strains CL-GR15 $5^{\mathrm{T}}$ and CL-GR35 contained three signature nucleotides that are types of compensatory transversion mutations (positions 678-712; Table 1) and a single transversion mutation (position 194; Table 1). Therefore, strains CL-GR15 ${ }^{\mathrm{T}}$ and CL-GR35 could be recognized as representing a distinct genus belonging to a new family within the order Rhizobiales.
Strains CL-GR15 ${ }^{\mathrm{T}}$ and CL-GR35 gave identical results for morphological, physiological and biochemical characteristics, and the results are given in the genus and species descriptions, Fig. 2, Supplementary Fig. S2 and Table 2. The DNA G + C content was $52.8-53.0 \mathrm{~mol} \%$. DNA-DNA hybridization experiments revealed high values $(>97 \%)$ for relatedness between strains CL-GR15 ${ }^{\mathrm{T}}$ and CL-GR35. DNA-DNA hybridization, phenotypic and chemotaxonomic characteristics revealed that they belonged to the same species.

In addition to phylogenetic differentiation of strains CLGR15 ${ }^{\mathrm{T}}$ and CL-GR35 from the other families of the order Rhizobiales, combinations of phenotypic and chemotaxonomic characteristics can differentiate the strains from members of other families (Table 2). The difference of $\mathrm{G}+\mathrm{C}$ contents between these strains and other species belonging to the families Bartonellaceae, Rhodobiaceae, 'Xanthobacteraceae' and Methylobacteriaceae was $>10 \mathrm{~mol} \%$ (Table 2), showing a distinct genetic difference. The major quinone for strains CL-GR $15^{\mathrm{T}}$ and CL-GR35

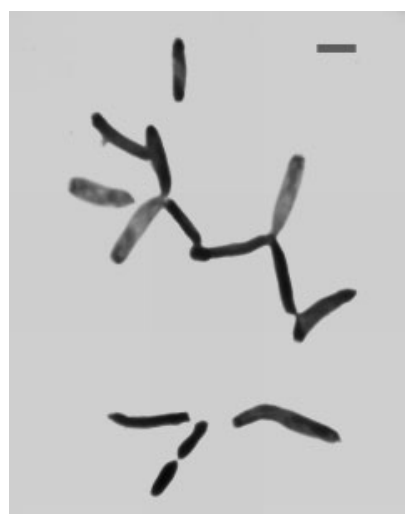

Fig. 2. Transmission electron micrograph of negatively stained cells of strain CL-GR15 ${ }^{\top}$. Bar, $1 \mu \mathrm{m}$. 


\section{Table 2. Differential characteristics of the families in the order Rhizobiales}

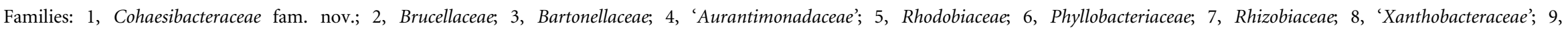

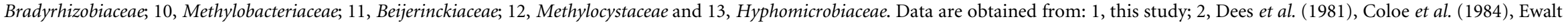

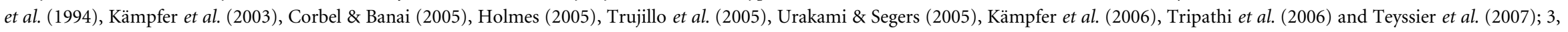

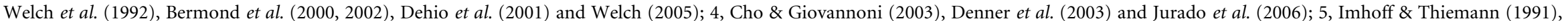

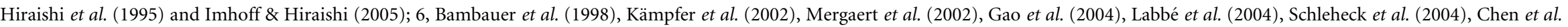

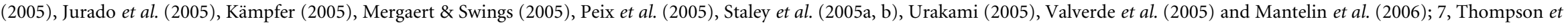

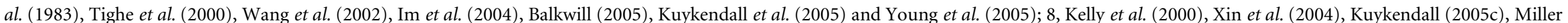

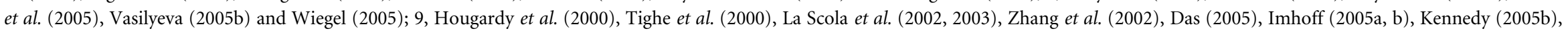

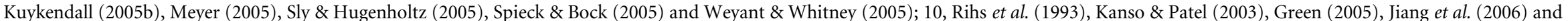

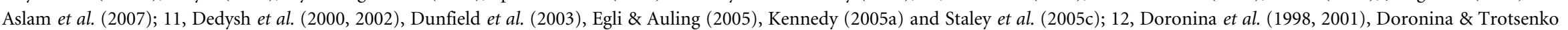

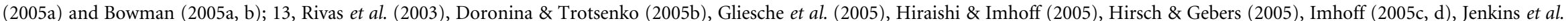

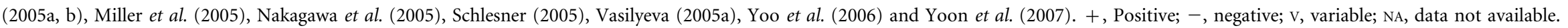

\begin{tabular}{|c|c|c|c|c|c|c|c|c|c|c|c|c|c|}
\hline Characteristic & 1 & 2 & 3 & 4 & 5 & 6 & 7 & 8 & 9 & 10 & 11 & 12 & 13 \\
\hline Nitrate reduction & - & $\mathrm{V}$ & - & - & $\mathrm{v}$ & $\mathrm{v}$ & + & $\mathrm{v}$ & $\mathrm{v}$ & $\mathrm{v}$ & $\mathrm{NA}$ & + & $\mathrm{v}$ \\
\hline Gelatin hydrolysis & + & - & - & - & - & $\mathrm{v}$ & - & $\mathrm{v}$ & - & $\mathrm{V}$ & $\mathrm{NA}$ & $\mathrm{V}$ & $\mathrm{v}$ \\
\hline Arginine dihydrolase & - & - & + & + & NA & - & - & $\mathrm{v}$ & - & NA & $\mathrm{NA}$ & NA & - \\
\hline Urease & - & $\mathrm{v}$ & - & + & NA & $\mathrm{v}$ & + & $\mathrm{v}$ & + & $\mathrm{v}$ & $\mathrm{v}$ & $\mathrm{v}$ & + \\
\hline Major quinone* & Q-10 & Q-10 & Q-10 & Q-10, Q-9 & $\begin{array}{l}\text { Q-10, } \\
\text { MK-10 }\end{array}$ & Q-10, Q-11 & Q-10 & Q-10 & $\begin{array}{l}\text { Q-10, } \\
\text { MK-10, } \\
\text { RQ-10 }\end{array}$ & Q-10 & Q-10 & Q-10, Q-8 & $\begin{array}{l}\text { Q-10, Q-9, } \\
\text { MK-9, RQ-10 }\end{array}$ \\
\hline Polar lipids $\dagger$ & $\begin{array}{l}\text { PC, PG, PE, } \\
\text { DPG, PME, } \\
\text { GL, ALs, Ls }\end{array}$ & $\begin{array}{c}\text { PC, PG, PE, } \\
\text { DPG PME, } \\
\text { AL (PS, PN, } \\
\text { PLs) }\end{array}$ & $\mathrm{NA}$ & $\begin{array}{c}\text { PC, PG, PE, } \\
\text { DPG, PME, } \\
\text { PDE, Ls }\end{array}$ & $\mathrm{NA}$ & $\begin{array}{c}\text { PC, PG, PE, } \\
\text { DPG (PME, } \\
\text { PDE, ALs, } \\
\text { PL) }\end{array}$ & $\begin{array}{l}\text { PC, PG, PE, } \\
\text { DPG, PME, } \\
\text { PDE }\end{array}$ & $\begin{array}{c}\mathrm{PE}, \mathrm{PDE} \\
(\mathrm{PC}, \mathrm{PG}, \\
\mathrm{PA})\end{array}$ & $\begin{array}{c}\text { PC, PG, PE, } \\
\text { DPG, ALs }\end{array}$ & $\begin{array}{c}\text { PC, PG, PE, } \\
\text { DPG }\end{array}$ & $\begin{array}{l}\text { PME (PG, } \\
\text { PE) }\end{array}$ & $\begin{array}{c}\text { PC, PG, PE, } \\
\text { PDE (PME, } \\
\text { PS, PL) }\end{array}$ & $\begin{array}{c}\text { PC, PG, PE, } \\
\text { DPG, PDE } \\
(\mathrm{PA}, \mathrm{BPG})\end{array}$ \\
\hline $\begin{array}{l}\text { DNA G +C content } \\
(\mathrm{mol} \%)\end{array}$ & $52.8-53.0$ & $54.5-59$ & $37-41$ & $57.6-66.3$ & $65.2-65.7$ & $53.1-65.1$ & $57-67.4$ & $65-70$ & $59-69$ & $63.5-72.4$ & $54.7-63.1$ & $61-70$ & $59-71.4$ \\
\hline
\end{tabular}

${ }^{\star} \mathrm{Q}$, Ubiquinone; MK, menaquinone; $\mathrm{RQ}$, rhodoquinone.

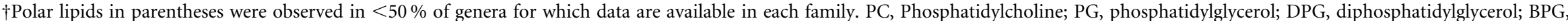

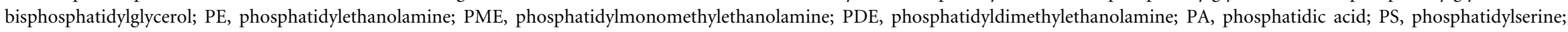
PN, aminophospholipid; PL, unidentified phospholipid; GL, unidentified glycolipid; AL, an unidentified aminolipid; L, an unidentified lipid. 
was ubiquinone-10 (Q-10), which is typically observed in the Alphaproteobacteria as the major quinone (Collins \& Jones, 1981; Kämpfer et al., 2003). However, the sole major respiratory quinone (Q-10) can differentiate strains CLGR15 ${ }^{\mathrm{T}}$ and CL-GR35 from the families 'Aurantimonadaceae, Phyllobacteriaceae, Rhodobiaceae, Bradyrhizobiaceae, Methylocystaceae and Hyphomicrobiaceae (Table 2). Polar lipid compositions conservatively differentiate the strains from the other 11 families in the order Rhizobiales, except the families Brucellaceae and Phyllobacteriaceae (Table 2). In particular, strains CL-GR $15^{\mathrm{T}}$ and CL-GR35 can be differentiated from species in the family Brucellaceae, which is the most closely related family to the two strains, by the presence of gelatinase and the inability to grow on blood agar. An unidentified aminolipid (AL1) in the profile of strain CL-GR15 ${ }^{\mathrm{T}}$ (Supplementary Fig. S3) apparently exhibited the same position as that of AL1, AL and AL1 in the polar lipid profiles of Ochrobactrum gallinifaecis, Ochrobactrum pseudintermedium and Pseudochrobactrum asaccharolyticum, respectively, belonging to the family Brucellaceae (Kämpfer et al., 2003, 2006; Teyssier et al., 2007). However, the presence of a significant amount of an unidentified glycolipid could clearly distinguish strain CLGR $15^{\mathrm{T}}$ from the above species in the family Brucellaceae. Overall, strains CL-GR $15^{\mathrm{T}}$ and CL-GR35 cannot be assigned to any previously recognized bacterial family or genus and thus can be described as a novel species within a new genus, Cohaesibacter gelatinilyticus gen. nov., sp. nov., in a new family, Cohaesibacteraceae fam. nov.

\section{Description of Cohaesibacteraceae fam. nov.}

Cohaesibacteraceae (Co.hae.si.bact.er.a'ce.ae. N.L. masc. n. Cohaesibacter, type genus of the family; -aceae ending to denote a family; N.L. fem. pl. n. Cohaesibacteraceae, the Cohaesibacter family).

On the basis of 16S rRNA gene sequence analysis and combinations of genotypic, phenotypic and chemotaxonomic characteristics, the family is a member of the order Rhizobiales in the class Alphaproteobacteria with the following nucleotide sequence characteristics: 194 (T), 678 (A) and 712 (T). The type genus is Cohaesibacter.

\section{Description of Cohaesibacter gen. nov.}

Cohaesibacter [Co.hae.s'i.bac.ter. L. part. adj. cohaesus (from L. v. cohaereo) pressed together, clung together; N.L. masc. n. bacter a rod; N.L. masc. n. Cohaesibacter rods that appear cohesive with each other].

Cells are Gram-negative, facultatively anaerobic rods. Oxidase- and catalase-positive. The predominant fatty acids are $\mathrm{C}_{18: 1} \omega 7 c$ and $\mathrm{C}_{15: 0}$ iso $2-\mathrm{OH}$ and/or $\mathrm{C}_{16: 1} \omega 7 c$ and $\mathrm{C}_{20: 1} \omega 7 c$. The respiratory quinone is Q-10. The DNA $\mathrm{G}+\mathrm{C}$ content of the type species is approximately $53 \mathrm{~mol} \%$. The major polar lipids are phosphatidylcholine, phosphatidylglycerol, diphosphatidylglycerol, phosphatidylethanolamine, phosphatidylmonomethylethanolamine, an unidentified aminolipid (AL1) and an unidentified glycolipid. The genus is a member of the family Cohaesibacteraceae. The type species is Cohaesibacter gelatinilyticus.

\section{Description of Cohaesibacter gelatinilyticus sp. nov.}

Cohaesibacter gelatinilyticus (ge.la.ti.ni.ly'ti.cus. N.L. n. gelatinum gelatin; Gr. adj. lutikos able to dissolve; N.L. adj. lyticus dissolving; N.L. masc. adj. gelatinilyticus gelatindissolving).

In addition to the characteristics reported for the genus, cells are weakly motile by a polar flagellum and approximately $0.2-0.4 \mu \mathrm{m}$ wide and $1.0-3.0 \mu \mathrm{m}$ long. Reproduce by budding or binary fission or asymmetric division. Rosette formation occurs. Intracellular granules of poly- $\beta$-hydroxybutyrate are formed. No growth occurs on TSA, fivefold-diluted TSA, Czapek-Dox agar, MacConkey agar, blood agar or the above media supplemented with either $3 \%(\mathrm{w} / \mathrm{v}) \mathrm{NaCl}$ or $3 \%(\mathrm{w} / \mathrm{v})$ sea salts. On MA or R2A agar supplemented with $3 \%(\mathrm{w} / \mathrm{v}) \mathrm{NaCl}$, colonies are circular, entire, convex and creamy white in colour. After incubation for 1 week at optimal growth conditions, colonies are approximately $2 \mathrm{~mm}$ in diameter. Grows at temperatures in the range $15-31{ }^{\circ} \mathrm{C}$ (optimum, $25-30{ }^{\circ} \mathrm{C}$ ) and at $\mathrm{pH}$ 6-9 (optimum $\mathrm{pH} 8$ ). Growth occurs with $\mathrm{NaCl}$ concentrations of $2-5 \%(\mathrm{w} / \mathrm{v}$, optimum $3 \%)$. Casein, cellulose, xanthine and hypoxanthine are decomposed. Hydrolyses gelatin and aesculin. Negative for nitrate reduction, indole production, arginine dihydrolase and urease. Alkaline phosphatase and trypsin activities are present, and esterase (C4), esterase lipase (C8), leucine arylamidase, acid phosphatase, naphthol-phosphohydrolase and $N$-acetyl- $\beta$-glucosaminidase activities are weakly present. Lipase (C14), valine arylamidase, cystine arylamidase, $\alpha$-chymotrypsin, $\alpha$ - and $\beta$-glucosidase, $\alpha$ - and $\beta$ galactosidase, $\alpha$-mannosidase and $\alpha$-fucosidase activities are absent. Acid is produced from glycerol, DL-arabinose, D-ribose, DL-xylose, D-glucose, D-fructose, D-mannose, inositol, D-mannitol, D-sorbitol, $\mathrm{N}$-acetylglucosamine, Dlyxose, L-fucose, potassium gluconate and potassium 5ketogluconate, but not from erythritol, D-adonitol, methyl $\beta$-D-xylopyranoside, D-galactose, L-sorbose, L-rhamnose, dulcitol, methyl $\alpha$-D-mannopyranoside, methyl $\alpha$-D-glucopyranoside, amygdalin, arbutin, aesculin, salicin, D-cellobiose, maltose, D-lactose, melibiose, sucrose, trehalose, inulin, melezitose, raffinose, starch, glycogen, xylitol, gentiobiose, turanose, D-tagatose, D-fucose, DL-arabitol or potassium 2-ketogluconate. Growth occurs on acetate, $\alpha$ ketobutyric acid, citrate, D-fructose, D-glucose, mannitol, D-mannose, ribose, sorbitol, glutamic acid, glycerol, glycogen, inositol, inulin, L-arginine, L-asparagine, L-lysine, L-ornithine, $\mathrm{N}$-acetylglucosamine, polyethylene glycol, Lpyruvate, sodium succinate, sucrose, thiamine, Casamino acids, L-proline, peptone, tryptone and yeast extract. No growth occurs on acetamide, benzoate, DL-cysteine, 
cellobiose, D-galactose, raffinose, salicin, trehalose, Lxylose, ethanol, formic acid, glycine, 2-propanol, D-lactose, L-arabinose, ascorbate, L-rhamnose, maleic acid, oxalic acid, salicylate, tartrate or urea. Cells are sensitive to ( $\mu \mathrm{g}$ per disc) gentamicin (6), cephalexin (20), vancomycin (20), mitomycin C (0.6), kanamycin (20), penicillin (6), erythromycin (10), chloramphenicol (20), ciprofloxacin (3) and ampicillin (6), but resistant to tetracycline (20), nalidixic acid (20) and streptomycin (6). The fatty acids are $\mathrm{C}_{18: 1} \omega 7 c(54.3-55.1 \%)$ and $\mathrm{C}_{15: 0}$ iso $2-\mathrm{OH}$ and/or $\mathrm{C}_{16: 1} \omega 7 c$ (summed feature 3; 19.2-20.4\%), $\mathrm{C}_{20: 1} \omega 7 c$ (9.6-11.1\%), $\mathrm{C}_{18: 0}(3.1-3.3 \%), \mathrm{C}_{14: 0} 3-\mathrm{OH}$ and/or $\mathrm{C}_{16: 1}$ iso $\mathrm{I}(3.0 \%), \mathrm{C}_{18: 0} 3-\mathrm{OH}(1.9-2.0 \%), \mathrm{C}_{17: 1} \omega 8 c(1.1-$ $1.5 \%)$ and $\mathrm{C}_{16: 0}(1.1 \%)$. Other minor fatty acids $(<1 \%)$ are $\mathrm{C}_{9: 0}, \mathrm{C}_{14: 0}, \mathrm{C}_{17: 0}, \mathrm{C}_{19: 0}, \mathrm{C}_{20: 0}, \mathrm{C}_{14: 1} \omega 5 c, \mathrm{C}_{19: 0}$ cyclo $\omega 8 c, \mathrm{C}_{16: 0} 3-\mathrm{OH}, \mathrm{C}_{17: 0}$ iso 3-OH and $\mathrm{C}_{19: 0} 10$-methyl. In addition to the polar lipids listed in the genus description, minor amounts of an unidentified aminolipid (AL2) and unidentified lipids (L1-4) can be detected.

The type strain, CL-GR $15^{\mathrm{T}} \quad\left(=\mathrm{KCCM} \quad 42319^{\mathrm{T}}=\mathrm{DSM}\right.$ $\left.18289^{\mathrm{T}}\right)$, was isolated from coastal water of the east coast of Korea.

\section{Acknowledgements}

We acknowledge the expert technical support of Ms M. J. Kang in operating the electron microscope at the National Center for Interuniversity Research Facilities at the Seoul National University. This work was (in part) supported by the BK21 project of the Korean Government and a project (A04NJ08) of Korea Hydro \& Nuclear Power Co. Ltd.

\section{References}

Altschul, S. F., Gish, W., Miller, W., Myers, E. W. \& Lipman, D. J. (1990). Basic local alignment search tool. J Mol Biol 215, 403-410.

Aslam, Z., Lee, C. S., Kim, K.-H., Im, W.-T., Ten, L. N. \& Lee, S.-T. (2007). Methylobacterium jeotgali sp. nov., a non-pigmented, facultatively methylotrophic bacterium isolated from jeotgal, a traditional Korean fermented seafood. Int J Syst Evol Microbiol 57, 566-571.

Balkwill, D. L. (2005). Genus VI. Ensifer Casida 1982, 343 ${ }^{\mathrm{VP}}$. In Bergey's Manual of Systematic Bacteriology, 2nd edn, vol. 2, part C, pp. 354-358. Edited by D. J. Brenner, N. R. Krieg, J. T. Staley \& G. M. Garrity. New York: Springer.

Bambauer, A., Rainey, F. A., Stackebrandt, E. \& Winter, J. (1998). Characterization of Aquamicrobium defluvii gen. nov. sp. nov., a thiophene-2-carboxylate-metabolizing bacterium from activated sludge. Arch Microbiol 169, 293-302.

Bauer, A. W., Kirby, W. M. M., Sherris, J. C. \& Turck, M. (1966). Antibiotic susceptibility testing by a standardized single disk method. Am J Clin Pathol 45, 493-496.

Baumann, P. \& Baumann, L. (1981). The marine Gram-negative eubacteria: genera Photobacterium, Beneckea, Alteromonas, Pseudomonas, and Alcaligenes. In The Prokaryotes, pp. 1302-1331. Edited by M. P. Starr, H. Stolp, H. G. Trüper, A. Balows \& H. G. Schlegel. Berlin: Springer-Verlag.

Bermond, D., Heller, R., Barrat, F., Delacour, G., Dehio, C., Alliot, A., Monteil, H., Chomel, B., Boulouis, H.-J. \& Piémont, Y. (2000).
Bartonella birtlesii sp. nov., isolated from small mammals (Apodemus spp.). Int J Syst Evol Microbiol 50, 1973-1979.

Bermond, D., Boulouis, H.-J., Heller, R., Van Laere, G., Monteil, H., Chomel, B. B., Sander, A., Dehio, C. \& Piémont, Y. (2002). Bartonella bovis Bermond et al. sp. nov. and Bartonella capreoli sp. nov., isolated from European ruminants. Int J Syst Evol Microbiol 52, 383-390.

Bowman, J. P. (2005a). Genus I. Methylocystis (ex Romanovskaya, Malashenko and Bogachenko 1978) Bowman, Sly, Nichols and Hayward 1993c, $751^{\mathrm{VP}}$. In Bergey's Manual of Systematic Bacteriology, 2nd edn, vol. 2, part C, pp. 413-416. Edited by D. J. Brenner, N. R. Krieg, J. T. Staley \& G. M. Garrity. New York: Springer.

Bowman, J. P. (2005b). Genus III. Methylosinus (ex Romanovskaya, Malashenko and Bogachenko 1978) Bowman, Sly, Nichols and Hayward 1993c, 751 VP. In Bergey's Manual of Systematic Bacteriology, 2nd edn, vol. 2, part C, pp. 417-420. Edited by D. J. Brenner, N. R. Krieg, J. T. Staley \& G. M. Garrity. New York: Springer.

Chen, W. X., Wang, E. T. \& Kuykendall, L. D. (2005). Genus VI. Mesorhizobium Jarvis, van Berkum, Chen, Nour, Fernandez, CleyetMarel and Gillis 1997, 897 $7^{\mathrm{VP}}$. In Bergey's Manual of Systematic Bacteriology, 2nd edn, vol. 2, part C, pp. 403-408. Edited by D. J. Brenner, N. R. Krieg, J. T. Staley \& G. M. Garrity. New York: Springer.

Cho, J.-C. \& Giovannoni, S. J. (2003). Fulvimarina pelagi gen. nov., sp. nov., a marine bacterium that forms a deep evolutionary lineage of descent in the order 'Rhizobiales'. Int J Syst Evol Microbiol 53, 1853-1859.

Choi, D. H., Kim, Y.-G., Hwang, C. Y., Yi, H., Chun, J. \& Cho, B. C. (2006). Tenacibaculum litoreum sp. nov., isolated from tidal flat sediment. Int J Syst Evol Microbiol 56, 635-640.

Cole, J. R., Chai, B., Marsh, T. L., Farris, R. J., Wang, Q., Kulam, S. A., Chandra, S., McGarrell, D. M., Schmidt, T. M. \& other authors (2003). The Ribosomal Database Project (RDP-II): previewing a new autoaligner that allows regular updates and the new prokaryotic taxonomy. Nucleic Acids Res 31, 442-443.

Collins, M. D. (1985). Isoprenoid quinone analysis in classification and identification. In Chemical Methods in Bacterial Systematics, pp. 267-287. Edited by M. Goodfellow \& D. E. Minnikin. London: Academic Press.

Collins, M. D. \& Jones, D. (1981). Distribution of isoprenoid quinone structural types in bacteria and their taxonomic implications. Microbiol Rev 45, 316-354.

Coloe, P. J., Sinclair, A. J., Slattery, J. F. \& Burke, D. (1984). Differentiation of Brucella ovis from Brucella abortus by gas-liquid chromatographic analysis of cellular fatty acids. J Clin Microbiol 19, 896-898.

Corbel, M. J. \& Banai, M. (2005). Genus I. Brucella Meyer and Shaw $1920,173^{\mathrm{AL}}$. In Bergey's Manual of Systematic Bacteriology, 2nd edn, vol. 2, part C, pp. 370-386. Edited by D. J. Brenner, N. R. Krieg, J. T. Staley \& G. M. Garrity. New York: Springer.

Das, S. K. (2005). Genus V. Bosea Das, Mishra, Tindall, Rainey and Stackebrandt 1996, 985 ${ }^{\mathrm{VP}}$. In Bergey's Manual of Systematic Bacteriology, 2nd edn, vol. 2, part C, pp. 459-461. Edited by D. J. Brenner, N. R. Krieg, J. T. Staley \& G. M. Garrity. New York: Springer.

Dedysh, S. N., Liesack, W., Khmelenina, V. N., Suzina, N. E., Trotsenko, Y. A., Semrau, J. D., Bares, A. M., Panikov, N. S. \& Tiedje, J. M. (2000). Methylocella palustris gen. nov., sp. nov., a new methaneoxidizing acidophilic bacterium from peat bogs, representing a novel subtype of serine-pathway methanotrophs. Int J Syst Evol Microbiol 50, 955-969. 
Dedysh, S. N., Khmelenina, V. N., Suzina, N. E., Trotsenko, Y. A., Semrau, J. D., Liesack, W. \& Tiedje, J. M. (2002). Methylocapsa acidiphila gen. nov., sp. nov., a novel methane-oxidizing and dinitrogen-fixing acidophilic bacterium from Sphagnum bog. Int $J$ Syst Evol Microbiol 52, 251-261.

Dees, S. B., Hollis, D. G., Weaver, R. E. \& Moss, C. W. (1981). Cellular fatty acids of Brucella canis and Brucella suis. J Clin Microbiol 14, 111-112.

Dehio, C., Lanz, C., Pohl, R., Behrens, P., Bermond, D., Piémont, Y., Pelz, K. \& Sander, A. (2001). Bartonella schoenbuchii sp. nov., isolated from the blood of wild roe deer. Int J Syst Evol Microbiol 51, 1557-1565.

Denner, E. B. M., Smith, G. W., Busse, H.-J., Schumann, P., Narzt, T., Polson, S. W., Lubitz, W. \& Richardson, L. L. (2003). Aurantimonas coralicida gen. nov., sp. nov., the causative agent of white plague type II on Caribbean scleractinian corals. Int J Syst Evol Microbiol 53, $1115-1122$.

Doronina, N. V. \& Trotsenko, Y. A. (2005a). Genus Incertae Sedis IV. Methylopila Doronina, Trotsenko, Krausova, Boulygina and Tourova $1998 \mathrm{a}, 1319^{\mathrm{VP}}$. In Bergey's Manual of Systematic Bacteriology, 2nd edn, vol. 2, part C, pp. 420-422. Edited by D. J. Brenner, N. R. Krieg, J. T. Staley \& G. M. Garrity. New York: Springer.

Doronina, N. V. \& Trotsenko, Y. A. (2005b). Genus XIII. Methylorhabdus Doronina, Braus-Stromeyer, Leisinger and Trotsenko 1996a, 362 ${ }^{\mathrm{VP}}$ (Effective publication: Doronina, BrausStromeyer, Leisinger and Trotsenko 1995, 97). In Bergey's Manual of Systematic Bacteriology, 2nd edn, vol. 2, part C, pp. 525-527. Edited by D. J. Brenner, N. R. Krieg, J. T. Staley \& G. M. Garrity. New York: Springer.

Doronina, N. V., Trotsenko, Y. A., Krausova, V. I., Boulygina, E. S. \& Tourova, T. P. (1998). Methylopila capsulata gen. nov., sp. nov., a novel non-pigmented aerobic facultatively methylotrophic bacterium. Int J Syst Evol Microbiol 48, 1313-1321.

Doronina, N. V., Trotsenko, Y. A., Tourova, T. P., Kuznetsov, B. B. \& Leisinger, T. (2001). Albibacter methylovorans gen. nov., sp. nov., a novel aerobic, facultatively autotrophic and methylotrophic bacterium that utilizes dichloromethane. Int J Syst Evol Microbiol 51, 1051-1058.

Dunfield, P. F., Khmelenina, V. N., Suzina, N. E., Trotsenko, Y. A. \& Dedysh, S. N. (2003). Methylocella silvestris sp. nov., a novel methanotroph isolated from an acidic forest cambisol. Int J Syst Evol Microbiol 53, 1231-1239.

Egli, T. W. \& Auling, G. (2005). Genus II. Chelatococcus Auling, Busse, Egli, El-Banna and Stackebrandt 1993b, 624 ${ }^{\mathrm{VP}}$ (Effective publication: Auling, Busse, Egli, El-Banna and Stackebrandt 1993a, 109). In Bergey's Manual of Systematic Bacteriology, 2nd edn, vol. 2, part C, pp. 433-437. Edited by D. J. Brenner, N. R. Krieg, J. T. Staley \& G. M. Garrity. New York: Springer.

Ewalt, D. R., Payeur, J. B., Martin, B. M., Cummins, D. R. \& Miller, W. G. (1994). Characteristics of a Brucella species from a bottlenose dolphin (Tursiops truncatus). J Vet Diagn Invest 6, 448-452.

Fitch, W. M. (1971). Toward defining the course of evolution: minimum change for a specific tree topology. Syst Zool 20, 406-416.

Gao, J.-L., Turner, S. L., Kan, F. L., Wang, E. T., Tan, Z. Y., Qiu, Y. H., Gu, J., Terefework, Z., Young, J. P. W. \& other authors (2004). Mesorhizobium septentrionale sp. nov. and Mesorhizobium temperatum sp. nov., isolated from Astragalus adsurgens growing in the northern regions of China. Int J Syst Evol Microbiol 54, 2003-2012.

Garrity, G. M., Bell, J. A. \& Lilburn, T. G. (2004). Taxonomic Outline of the Prokaryotes. Bergey's Manual of Systematic Bacteriology, 2nd edn. Release 5.0. New York: Springer. http://dx.doi.org/10.1007/bergeysoutline
Garrity, G. M., Bell, J. A. \& Liburn, T. (2005). Class I. Alphaproteobacteria class. nov. In Bergey's Manual of Systematic Bacteriology, 2nd edn, vol. 2, part C, p. 1. Edited by D. J. Brenner, N. R. Krieg, J. T. Staley \& G. M. Garrity. New York: Springer.

Gliesche, C., Fesefeldt, A. \& Hirsch, P. (2005). Genus I. Hyphomicrobium Stutzer and Hartleb 1898, $76^{\mathrm{AL}}$. In Bergey's Manual of Systematic Bacteriology, 2nd edn, vol. 2, part C, pp. 476494. Edited by D. J. Brenner, N. R. Krieg, J. T. Staley \& G. M. Garrity. New York: Springer.

Green, P. N. (2005). Genus I. Methylobacterium Patt, Cole and Hanson 1976, 228 ${ }^{\mathrm{AL}}$ emend. Green and Bousfield 1983, 876. In Bergey's Manual of Systematic Bacteriology, 2nd edn, vol. 2, part C, pp. 567-571. Edited by D. J. Brenner, N. R. Krieg, J. T. Staley \& G. M. Garrity. New York: Springer.

Hiraishi, A. \& Imhoff, J. F. (2005). Genus XVII. Rhodoplanes Hiraishi and Ueda 1994b, 671 ${ }^{\mathrm{VP}}$. In Bergey's Manual of Systematic Bacteriology, 2nd edn, vol. 2, part C, pp. 545-549. Edited by D. J. Brenner, N. R. Krieg, J. T. Staley \& G. M. Garrity. New York: Springer.

Hiraishi, A., Urata, K. \& Satoh, T. (1995). A new genus of marine budding phototrophic bacteria, Rhodobium gen. nov., which includes Rhodobium orientis sp. nov. and Rhodobium marinum comb. nov. Int J Syst Bacteriol 45, 226-234.

Hirsch, P. \& Gebers, R. (2005). Genus XIV. Pedomicrobium Aristovskaya 1961, 957 ${ }^{\mathrm{VP}}$ emend. Gebers and Beese 1988, 305. In Bergey's Manual of Systematic Bacteriology, 2nd edn, vol. 2, part C, pp. 527-538. Edited by D. J. Brenner, N. R. Krieg, J. T. Staley \& G. M. Garrity. New York: Springer.

Holmes, B. (2005). Genus III. Ochrobactrum Holmes, Popoff, Kiredjian and Kersters 1988, 412 ${ }^{\mathrm{VP}}$. In Bergey's Manual of Systematic Bacteriology, 2nd edn, vol. 2, part C, pp. 389-392. Edited by D. J. Brenner, N. R. Krieg, J. T. Staley \& G. M. Garrity. New York: Springer.

Hougardy, A., Tindall, B. J. \& Klemme, J.-H. (2000). Rhodopseudomonas rhenobacensis sp. nov., a new nitrate-reducing purple non-sulfur bacterium. Int J Syst Evol Microbiol 50, 985-992.

Im, W.-T., Yokota, A., Kim, M.-K. \& Lee, S.-T. (2004). Kaistia adipata gen. nov., sp. nov., a novel $\alpha$-proteobacterium. J Gen Appl Microbiol 50, 249-254

Imhoff, J. F. (2005a). Genus VIII. Rhodoblastus Imhoff 2001, $1865^{\mathrm{VP}}$. In Bergey's Manual of Systematic Bacteriology, 2nd edn, vol. 2, part C, pp. 471-473. Edited by D. J. Brenner, N. R. Krieg, J. T. Staley \& G. M. Garrity. New York: Springer.

Imhoff, J. F. (2005b). Genus IX. Rhodopseudomonas Czurda and Maresch 1937, $119^{\mathrm{AL}}$ emend. Imhoff, Trüper and Pfennig 1984, 341. In Bergey's Manual of Systematic Bacteriology, 2nd edn, vol. 2, part C, pp. 473-476. Edited by D. J. Brenner, N. R. Krieg, J. T. Staley \& G. M. Garrity. New York: Springer.

Imhoff, J. F. (2005c). Genus VII. Blastochloris Hiraishi 1997, $218^{\mathrm{VP}}$. In Bergey's Manual of Systematic Bacteriology, 2nd edn, vol. 2, part C, pp. 506-509. Edited by D. J. Brenner, N. R. Krieg, J. T. Staley \& G. M. Garrity. New York: Springer.

Imhoff, J. F. (2005d). Genus XVI. Rhodomicrobium Duchow and Douglas 1949, $415^{\mathrm{AL}}$ emend. Imhoff, Trüper and Pfennig 1984, 341. In Bergey's Manual of Systematic Bacteriology, 2nd edn, vol. 2, part C, pp. 543-545. Edited by D. J. Brenner, N. R. Krieg, J. T. Staley \& G. M. Garrity. New York: Springer.

Imhoff, J. F. \& Hiraishi, A. (2005). Genus I. Rhodobium Hiraishi, Urata and Satoh 1995d, 230 VP. In Bergey's Manual of Systematic Bacteriology, 2nd edn, vol. 2, part C, pp. 571-574. Edited by D. J. Brenner, N. R. Krieg, J. T. Staley \& G. M. Garrity. New York: Springer.

Imhoff, J. F. \& Thiemann, B. (1991). Influence of salt concentration and temperature on the fatty acid compositions of Ectothiorhodospira 
and other halophilic phototrophic purple bacteria. Arch Microbiol 156, 370-375.

Ivanova, E. P., Flavier, S. \& Christen, R. (2004). Phylogenetic relationships among marine Alteromonas-like proteobacteria: emended description of the family Alteromonadaceae and proposal of Pseudoalteromonadaceae fam. nov., Colwelliaceae fam. nov., Shewanellaceae fam. nov., Idiomarinaceae fam. nov. and Psychromonadaceae fam. nov. Int J Syst Evol Microbiol 54, 1773-1788.

Jenkins, C., Stanley, P. M. \& Staley, J. T. (2005a). Genus II. Ancalomicrobium Staley 1968, 1940 ${ }^{\mathrm{AL}}$. In Bergey's Manual of Systematic Bacteriology, 2nd edn, vol. 2, part C, pp. 494-497. Edited by D. J. Brenner, N. R. Krieg, J. T. Staley \& G. M. Garrity. New York: Springer.

Jenkins, C., Rainey, F. A., Ward, N. L. \& Staley, J. T. (2005b). Genus XV. Prosthecomicrobium Staley 1968, 1940 ${ }^{\mathrm{AL}}$ emend. Staley 1984, 304. In Bergey's Manual of Systematic Bacteriology, 2nd edn, vol. 2, part C, pp. 538-543. Edited by D. J. Brenner, N. R. Krieg, J. T. Staley \& G. M. Garrity. New York: Springer.

Jeon, Y.-S., Chung, H., Park, S., Hur, I., Lee, J.-H. \& Chun, J. (2005). jPHYDIT: a JAVA-based integrated environment for molecular phylogeny of ribosomal RNA sequences. Bioinformatics 21, 3171-3173.

Jiang, C.-Y., Dai, X., Wang, B.-J., Zhou, Y.-G. \& Liu, S.-J. (2006). Roseomonas lacus sp. nov., isolated from freshwater lake sediment. Int J Syst Evol Microbiol 56, 25-28.

Jukes, T. H. \& Cantor, C. R. (1969). Evolution of protein molecules. In Mammalian Protein Metabolism, vol. 3, pp. 21-132. Edited by H. N. Munro. New York: Academic Press.

Jurado, V., Laiz, L., Gonzalez, J. M., Hernandez-Marine, M., Valens, M. \& Saiz-Jimenez, C. (2005). Phyllobacterium catacumbae sp. nov., a member of the order 'Rhizobiales' isolated from Roman catacombs. Int J Syst Evol Microbiol 55, 1487-1490.

Jurado, V., Gonzalez, J. M., Laiz, L. \& Saiz-Jimenez, C. (2006). Aurantimonas altamirensis sp. nov., a member of the order Rhizobiales isolated from Altamira Cave. Int J Syst Evol Microbiol 56, 2583-2585.

Kämpfer, P. (2005). Genus VII. Pseudaminobacter Kämpfer, Müller, Mau, Neef, Auling, Busse, Osborn and Stolz 1999, $894^{\mathrm{VP}}$. In Bergey's Manual of Systematic Bacteriology, 2nd edn, vol. 2, part C, pp. 409410. Edited by D. J. Brenner, N. R. Krieg, J. T. Staley \& G. M. Garrity. New York: Springer.

Kämpfer, P., Neef, A., Salkinoja-Salonen, M. S. \& Busse, H.-J. (2002). Chelatobacter heintzii (Auling et al. 1993) is a later subjective synonym of Aminobacter aminovorans (Urakami et al. 1992). Int J Syst Evol Microbiol 52, 835-839.

Kämpfer, P., Buczolits, S., Albrecht, A., Busse, H.-J. \& Stackebrandt, E. (2003). Towards a standardized format for the description of a novel species (of an established genus): Ochrobactrum gallinifaecis sp. nov. Int J Syst Evol Microbiol 53, 893-896.

Kämpfer, P., Rosselló-Mora, R., Scholz, H. C., Welinder-Olsson, C., Falsen, E. \& Busse, H.-J. (2006). Description of Pseudochrobactrum gen. nov., with two species Pseudochrobactrum asaccharolyticum sp. nov. and Pseudochrobactrum saccharolyticum sp. nov. Int J Syst Evol Microbiol 56, 1823-1829.

Kanso, S. \& Patel, B. K. C. (2003). Microvirga subterranea gen. nov., sp. nov., a moderate thermophile from a deep subsurface Australian thermal aquifer. Int J Syst Evol Microbiol 53, 401-406.

Kelly, D. P., McDonald, I. R. \& Wood, A. P. (2000). Proposal for the reclassification of Thiobacillus novellus as Starkeya novella gen. nov., comb. nov., in the $\alpha$-subclass of the Proteobacteria. Int J Syst Evol Microbiol 50, 1797-1802.

Kennedy, C. (2005a). Genus I. Beijerinckia Derx 1950a, $145^{\mathrm{AL}}$. In Bergey's Manual of Systematic Bacteriology, 2nd edn, vol. 2, part C, pp. 423-432. Edited by D. J. Brenner, N. R. Krieg, J. T. Staley \& G. M. Garrity. New York: Springer.

Kennedy, C. (2005b). Genus III. Agromonas Ohta and Hattori 1985, $223^{\mathrm{VP}}$ (Effective publication: Ohta and Hattori 1983, 43). In Bergey's Manual of Systematic Bacteriology, 2nd edn, vol. 2, part C, pp. 448452. Edited by D. J. Brenner, N. R. Krieg, J. T. Staley \& G. M. Garrity. New York: Springer.

Komagata, K. \& Suzuki, K. (1987). Lipids and cell-wall analysis in bacterial systematics. Methods Microbiol 19, 161-207.

Kumar, S., Tamura, K. \& Nei, M. (2004). MEGA3: integrated software for molecular evolutionary genetics analysis and sequence alignment. Brief Bioinform 5, 150-163.

Kuykendall, L. D. (2005a). Order VI. Rhizobiales ord. nov. In Bergey's Manual of Systematic Bacteriology, 2nd edn, vol. 2, part C, p. 324. Edited by D. J. Brenner, N. R. Krieg, J. T. Staley \& G. M. Garrity. New York: Springer.

Kuykendall, L. D. (2005b). Genus I. Bradyrhizobium Jordan 1982, $137^{\mathrm{VP}}$. In Bergey's Manual of Systematic Bacteriology, 2nd edn, vol. 2, part C, pp. 438-443. Edited by D. J. Brenner, N. R. Krieg, J. T. Staley \& G. M. Garrity. New York: Springer.

Kuykendall, L. D. (2005c). Genus VI. Azorhizobium Dreyfus, Garcia and Gillis 1988, 89 ${ }^{\mathrm{VP}}$. In Bergey's Manual of Systematic Bacteriology, 2nd edn, vol. 2, part C, pp. 505-506. Edited by D. J. Brenner, N. R. Krieg, J. T. Staley \& G. M. Garrity. New York: Springer.

Kuykendall, L. D., Hashem, F. M. \& Wang, E. T. (2005). Genus VII. Sinorhizobium Chen, Yan and Li 1988b, $396^{\mathrm{VP}}$ emend. de Lajudie, Willems, Pot, Dewettinck, Maestrojuan, Neyra, Collins, Dreyfus, Kersters and Gillis 1994, 732. In Bergey's Manual of Systematic Bacteriology, 2nd edn, vol. 2, part C, pp. 358-361. Edited by D. J. Brenner, N. R. Krieg, J. T. Staley \& G. M. Garrity. New York: Springer.

La Scola, B., Mallet, M.-N., Grimont, P. A. D. \& Raoult, D. (2002). Description of Afipia birgiae sp. nov. and Afipia massiliensis sp. nov. and recognition of Afipia felis genospecies A. Int J Syst Evol Microbiol 52, 1773-1782.

La Scola, B., Mallet, M.-N., Grimont, P. A. D. \& Raoult, D. (2003). Bosea eneae sp. nov., Bosea massiliensis sp. nov. and Bosea vestrisii sp. nov., isolated from hospital water supplies, and emendation of the genus Bosea (Das et al. 1996). Int J Syst Evol Microbiol 53, 15-20.

Labbé, N., Parent, S. \& Villemur, R. (2004). Nitratireductor aquibiodomus gen. nov., sp. nov., a novel $\alpha$-proteobacterium from the marine denitrification system of the Montreal Biodôme (Canada). Int J Syst Evol Microbiol 54, 269-273.

Lane, D. J. (1991). 16S/23S rRNA sequencing. In Nucleic Acid Techniques in Bacterial Systematics, pp. 115-175. Edited by E. Stackebrandt \& M. Goodfellow. Chichester: Wiley.

Lee, K.-B., Liu, C.-T., Anzai, Y., Kim, H., Aono, T. \& Oyaizu, H. (2005). The hierarchical system of the 'Alphaproteobacteria': description of Hyphomonadaceae fam. nov., Xanthobacteraceae fam. nov. and Erythrobacteraceae fam. nov. Int J Syst Evol Microbiol 55, 1907-1919.

Manaia, C. M., Nogales, B. \& Nunes, O. C. (2003). Tepidiphilus margaritifer gen. nov., sp. nov., isolated from a thermophilic aerobic digester. Int J Syst Evol Microbiol 53, 1405-1410.

Mantelin, S., Saux, M. F.-L., Zakhia, F., Béna, G., Bonneau, S., Jeder, H., de Lajudie, P. \& Cleyet-Marel, J.-C. (2006). Emended description of the genus Phyllobacterium and description of four novel species associated with plant roots: Phyllobacterium bourgognense sp. nov., Phyllobacterium ifriqiyense sp. nov., Phyllobacterium leguminum sp. nov. and Phyllobacterium brassicacearum sp. nov. Int J Syst Evol Microbiol 56, 827-839.

Marmur, J. (1961). A procedure for the isolation of deoxyribonucleic acid from microorganisms. J Mol Biol 3, 208-218. 
Mergaert, J. \& Swings, J. (2005). Genus I. Phyllobacterium (ex Knösel 1962) Knösel 1984b, 356 ${ }^{\mathrm{VP}}$ (Effective publication: Knösel 1984a, 254). In Bergey's Manual of Systematic Bacteriology, 2nd edn, vol. 2, part C, pp. 394-396. Edited by D. J. Brenner, N. R. Krieg, J. T. Staley \& G. M. Garrity. New York: Springer.

Mergaert, J., Cnockaert, M. C. \& Swings, J. (2002). Phyllobacterium myrsinacearum (subjective synonym Phyllobacterium rubiacearum) emend. Int J Syst Evol Microbiol 52, 1821-1823.

Mesbah, M., Premachandran, U. \& Whitman, W. B. (1989). Precise measurement of the $\mathrm{G}+\mathrm{C}$ content of deoxyribonucleic acid by highperformance liquid chromatography. Int J Syst Bacteriol 39, 159-167.

Meyer, O. O. (2005). Genus VII. Oligotropha Meyer, Stackebrandt and Auling 1994, 182 ${ }^{\mathrm{VP}}$ (Effective publication: Meyer, Stackebrandt and Auling 1993, 391). In Bergey's Manual of Systematic Bacteriology, 2nd edn, vol. 2, part C, pp. 468-471. Edited by D. J. Brenner, N. R. Krieg, J. T. Staley \& G. M. Garrity. New York: Springer.

Miller, J. A., Kalyuzhnaya, M. G., Noyes, E., Lara, J. C., Lidstrom, M. E. \& Chistoserdova, L. (2005). Labrys methylaminiphilus sp. nov., a novel facultatively methylotrophic bacterium from a freshwater lake sediment. Int J Syst Evol Microbiol 55, 1247-1253.

Minnikin, D. E., O'Donnell, A. G., Goodfellow, M., Alderson, G., Athalye, M., Schaal, K. \& Parlett, J. H. (1984). An integrated procedure for the extraction of bacterial isoprenoid quinones and polar lipids. J Microbiol Methods 2, 233-241.

Nakagawa, Y., Sakane, T. \& Yokota, A. (2005). Genus VIII. Devosia Nakagawa, Sakane and Yokota 1996, 20 $\mathrm{VP}$. In Bergey's Manual of Systematic Bacteriology, 2nd edn, vol. 2, part C, pp. 509-512. Edited by D. J. Brenner, N. R. Krieg, J. T. Staley \& G. M. Garrity. New York: Springer.

Ostle, A. G. \& Holt, J. G. (1982). Nile blue A as fluorescent stain for poly- $\beta$-hydroxybutyrate. Appl Environ Microbiol 44, 238-241.

Peix, A., Rivas, R., Trujillo, M. E., Vancanneyt, M., Velázquez, E. \& Willems, A. (2005). Reclassification of Agrobacterium ferrugineum LMG 128 as Hoeflea marina gen. nov., sp. nov. Int J Syst Evol Microbiol 55, 1163-1166.

Rihs, J. D., Brenner, D. J., Weaver, R. E., Steigerwalt, A. G., Hollis, D. G. \& Yu, V. L. (1993). Roseomonas, a new genus associated with bacteremia and other human infections. J Clin Microbiol 31, 3275-3283.

Rivas, R., Sánchez, M., Trujillo, M. E., Zurdo-Piñeiro, J. L., Mateos, P. F., Martínez-Molina, E. \& Velázquez, E. (2003). Xylanimonas cellulosilytica gen. nov., sp. nov., a xylanolytic bacterium isolated from a decayed tree (Ulmus nigra). Int J Syst Evol Microbiol 53, 99-103.

Saitou, N. \& Nei, M. (1987). The neighbor-joining method: a new method for reconstructing phylogenetic trees. Mol Biol Evol 4, 406-425.

Schleheck, D., Tindall, B. J., Rosselló-Mora, R. \& Cook, A. M. (2004). Parvibaculum lavamentivorans gen. nov., sp. nov., a novel heterotroph that initiates catabolism of linear alkylbenzenesulfonate. Int J Syst Evol Microbiol 54, 1489-1497.

Schlesner, H. (2005). Genus X. Filomicrobium Schlesner 1988, $220^{\mathrm{VP}}$ (Effective publication: Schlesner 1987, 65). In Bergey's Manual of Systematic Bacteriology, 2nd edn, vol. 2, part C, pp. 518-520. Edited by D. J. Brenner, N. R. Krieg, J. T. Staley \& G. M. Garrity. New York: Springer.

Sekar, R., Mills, D. K., Remily, E. R., Voss, J. D. \& Richardson, L. L. (2006). Microbial communities in the surface mucopolysaccharide layer and the black band microbial mat of black band-diseased Siderastrea siderea. Appl Environ Microbiol 72, 5963-5973.

Sly, L. I. \& Hugenholtz, P. (2005). Genus IV. Blastobacter Zavarzin 1961, 962 ${ }^{\mathrm{AL}}$ emend. Sly 1985, 44. In Bergey's Manual of Systematic Bacteriology, 2nd edn, vol. 2, part C, pp. 452-459. Edited by D. J.
Brenner, N. R. Krieg, J. T. Staley \& G. M. Garrity. New York: Springer.

Smibert, R. M. \& Krieg, N. R. (1994). Phenotypic characterization. In Methods for General and Molecular Bacteriology, pp. 607-654. Edited by P. Gerhardt, R. G. E. Murray, W. A. Wood \& N. R. Krieg. Washington DC: American Society for Microbiology.

Spieck, E. \& Bock, E. (2005). Genus VI. Nitrobacter Winogradsky 1892, $127^{\mathrm{AL}}$ Nom. Cons. Opin. 23 Jud. Comm. 1958, 169. In Bergey's Manual of Systematic Bacteriology, 2nd edn, vol. 2, part C, pp. 461468. Edited by D. J. Brenner, N. R. Krieg, J. T. Staley \& G. M. Garrity. New York: Springer.

Staley, J. T., Boone, D. R., Brenner, D. J., De Vos, P., Garrity, G. M., Goodfellow, M., Krieg, N. R., Rainey, F. A. \& Schleifer, K.-H. (2005a). Genus III. Aquamicrobium Bambauer, Rainey, Stackebrandt and Winter 1998b, 631 $\mathrm{VP}$ (Effective publication: Bambauer, Rainey, Stackebrandt and Winter 1998a, 300). In Bergey's Manual of Systematic Bacteriology, 2nd edn, vol. 2, part C, pp. 399-400. Edited by D. J. Brenner, N. R. Krieg, J. T. Staley \& G. M. Garrity. New York: Springer.

Staley, J. T., Boone, D. R., Brenner, D. J., De Vos, P., Garrity, G. M., Goodfellow, M., Krieg, N. R., Rainey, F. A. \& Schleifer, K.-H. (2005b). Genus IV. Defluvibacter Fritsche, Auling, Andreesen and Lechner $1999 \mathrm{~b}, 1325^{\mathrm{VP}}$ (Effective publication: Fritsche, Auling, Andreesen and Lechner 1999a, 202). In Bergey's Manual of Systematic Bacteriology, 2nd edn, vol. 2, part C, p. 400. Edited by D. J. Brenner, N. R. Krieg, J. T. Staley \& G. M. Garrity. New York: Springer.

Staley, J. T., Boone, D. R., Brenner, D. J., De Vos, P., Garrity, G. M., Goodfellow, M., Krieg, N. R., Rainey, F. A. \& Schleifer, K.-H. (2005c). Genus III. Methylocella Dedysh, Liesack, Khmelenina, Suzina, Trotsenko, Semrau, Bares, Panikov and Tiedje 2000, 967 ${ }^{\mathrm{VP}}$. In Bergey's Manual of Systematic Bacteriology, 2nd edn, vol. 2, part C, p. 437. Edited by D. J. Brenner, N. R. Krieg, J. T. Staley \& G. M. Garrity. New York: Springer.

Teyssier, C., Marchandin, H., Jean-Pierre, H., Masnou, A., Dusart, G. \& Jumas-Bilak, E. (2007). Ochrobactrum pseudintermedium sp. nov., a novel member of the family Brucellaceae, isolated from human clinical samples. Int J Syst Evol Microbiol 57, 1007-1013.

Thompson, E. A., Kaufman, A. E., Johnston, N. C. \& Goldfine, H. (1983). Phospholipids of Rhizobium meliloti and Agrobacterium tumefaciens: lack of effect of Ti plasmid. Lipids 18, 602-606.

Tighe, S. W., de Lajudie, P., Dipietro, K., Lindström, K., Nick, G. \& Jarvis, B. D. W. (2000). Analysis of cellular fatty acids and phenotypic relationships of Agrobacterium, Bradyrhizobium, Mesorhizobium, Rhizobium and Sinorhizobium species using the Sherlock Microbial Identification System. Int J Syst Evol Microbiol 50, 787-801.

Tripathi, A. K., Verma, S. C., Chowdhury, S. P., Lebuhn, M., Gattinger, A. \& Schloter, M. (2006). Ochrobactrum oryzae sp. nov., an endophytic bacterial species isolated from deep-water rice in India. Int J Syst Evol Microbiol 56, 1677-1680.

Trujillo, M. E., Willems, A., Abril, A., Planchuelo, A.-M., Rivas, R., Ludeña, D., Mateos, P. F., Martínez-Molina, E. \& Velázquez, E. (2005). Nodulation of Lupinus albus by strains of Ochrobactrum lupini sp. nov. Appl Environ Microbiol 71, 1318-1327.

Urakami, T. (2005). Genus II. Aminobacter Urakami, Araki, Oyanagi, Suzuki and Komagata 1992, 90 ${ }^{\mathrm{VP}}$. In Bergey's Manual of Systematic Bacteriology, 2nd edn, vol. 2, part C, pp. 397-399. Edited by D. J. Brenner, N. R. Krieg, J. T. Staley \& G. M. Garrity. New York: Springer.

Urakami, T. \& Segers, P. (2005). Genus II. Mycoplana Gray and Thornton 1928, 82 ${ }^{\mathrm{AL}}$ emend. Urakami, Oyanagi, Araki, Suzuki and Komagata 1990d, 439. In Bergey's Manual of Systematic Bacteriology, 2nd edn, vol. 2, part C, pp. 386-389. Edited by D. J. Brenner, N. R. Krieg, J. T. Staley \& G. M. Garrity. New York: Springer. 
Valverde, A., Velázquez, E., Fernández-Santos, F., Vizcaíno, N., Rivas, R., Mateos, P. F., Martínez-Molina, E., Igual, J. M. \& Willems, A. (2005). Phyllobacterium trifolii sp. nov., nodulating Trifolium and Lupinus in Spanish soils. Int J Syst Evol Microbiol 55, 1985-1989.

Vandamme, P., Pot, B., Gillis, M., De Vos, P., Kersters, K. \& Swings, J. (1996). Polyphasic taxonomy, a consensus approach to bacterial systematics. Microbiol Rev 60, 407-438.

Vasilyeva, L. V. (2005a). Genus IV. Angulomicrobium Vasilyeva, Lafitskaya and Namsaraev 1986, 354 ${ }^{\mathrm{VP}}$ (Effective publication: Vasilyeva, Lafitskaya and Namsaraev 1979, 1037). In Bergey's Manual of Systematic Bacteriology, 2nd edn, vol. 2, part C, pp. 501504. Edited by D. J. Brenner, N. R. Krieg, J. T. Staley \& G. M. Garrity. New York: Springer.

Vasilyeva, L. V. (2005b). Genus XII. Labrys Vasilyeva and Semenov $1985,375^{\mathrm{VP}}$ (Effective publication: Vasilyeva and Semenov 1984, 92). In Bergey's Manual of Systematic Bacteriology, 2nd edn, vol. 2, part C, pp. 523-525. Edited by D. J. Brenner, N. R. Krieg, J. T. Staley \& G. M. Garrity. New York: Springer.

Wang, E. T., Tan, Z. Y., Willems, A., Fernández-López, M., ReinholdHurek, B. \& Martínez-Romero, E. (2002). Sinorhizobium morelense sp. nov., a Leucaena leucocephala-associated bacterium that is highly resistant to multiple antibiotics. Int J Syst Evol Microbiol 52, 1687-1693.

Welch, D. F. (2005). Genus I. Bartonella Strong, Tyzzer and Sellards $1915,808^{\mathrm{VP}}$ emend. Birtles, Harrison, Saunders and Molyneux 1995, 7. In Bergey's Manual of Systematic Bacteriology, 2nd edn, vol. 2, part C, pp. 362-370. Edited by D. J. Brenner, N. R. Krieg, J. T. Staley \& G. M. Garrity. New York: Springer.

Welch, D. F., Pickett, D. A., Slater, L. N., Steigerwalt, A. G. \& Brenner, D. J. (1992). Rochalimaea henselae sp. nov., a cause of septicemia, bacillary angiomatosis, and parenchymal bacillary peliosis. J Clin Microbiol 30, 275-280.

Weyant, R. S. \& Whitney, A. M. (2005). Genus II. Afipia Brenner, Hollis, Moss, English, Hall, Vincent, Radosevic, Birkness, Bibb and other authors 1992, $327^{\mathrm{VP}}$ (Effective publication: Brenner, Hollis,
Moss, English, Hall, Vincent, Radosevic, Birkness, Bibb and other authors, 1991, 2457). In Bergey's Manual of Systematic Bacteriology, 2nd edn, vol. 2, part C, pp. 443-448. Edited by D. J. Brenner, N. R. Krieg, J. T. Staley \& G. M. Garrity. New York: Springer.

Weyland, H. (1969). Actinomycetes in North Sea and Atlantic Ocean sediments. Nature 223, 858 .

Wiegel, J. K. W. (2005). Genus XX. Xanthobacter Wiegel, Wilke, Baumgarten, Opitz and Schlegel 1978, 573 ${ }^{\mathrm{AL}}$. In Bergey's Manual of Systematic Bacteriology, 2nd edn, vol. 2, part C, pp. 555-566. Edited by D. J. Brenner, N. R. Krieg, J. T. Staley \& G. M. Garrity. New York: Springer.

Woese, C. R., Stackebrandt, E., Weisburg, W. G., Paster, B. J., Madigan, M. T., Fowler, V. J., Hahn, C. M., Blanz, P., Gupta, R. \& other authors (1984). The phylogeny of purple bacteria: the alpha subdivision. Syst Appl Microbiol 5, 315-326.

Xin, Y. H., Zhou, Y. G., Zhou, H. L. \& Chen, W. X. (2004). Ancylobacter rudongensis sp. nov., isolated from roots of Spartina anglica. Int J Syst Evol Microbiol 54, 385-388.

Yoo, S.-H., Weon, H.-Y., Kim, B.-Y., Hong, S.-B., Kwon, S.-W., Cho, Y.-H., Go, S.-J. \& Stackebrandt, E. (2006). Devosia soli sp. nov., isolated from greenhouse soil in Korea. Int J Syst Evol Microbiol 56, 2689-2692.

Yoon, J.-H., Kang, S.-J., Park, S. \& Oh, T.-K. (2007). Devosia insulae sp. nov., isolated from soil, and emended description of the genus Devosia. Int J Syst Evol Microbiol 57, 1310-1314.

Young, J. M., Kerr, A. \& Sawada, H. (2005). Genus II. Agrobacterium Conn 1942, 359 ${ }^{\mathrm{AL}}$. In Bergey's Manual of Systematic Bacteriology, 2nd edn, vol. 2, part C, pp. 340-345. Edited by D. J. Brenner, N. R. Krieg, J. T. Staley \& G. M. Garrity. New York: Springer.

Zhang, D., Yang, H., Huang, Z., Zhang, W. \& Liu, S.-J. (2002). Rhodopseudomonas faecalis sp. nov., a phototrophic bacterium isolated from an anaerobic reactor that digests chicken faeces. Int $J$ Syst Evol Microbiol 52, 2055-2060. 